\title{
Auto/Biography and the Construction of Identity and Community in the Middle East
}

\author{
Mary Ann Fay, ed. \\ New York: Palgrave, 2001. 226 pages.
}

This collection of reflective essays and research articles argues for the greater use of auto/biographies, both as data sources and as representational texts, in examining individual and communal identity negotiations in the Middle East. It reflects the theoretical and topical shifts toward the local, regional, and particular that characterize poststructuralist and postmodernist social science research. It also resonates to the increased concern about representing marginalized populations in historical, sociological, and anthropological literature. Positing that "biography lies at the intersection of the personal and the political and of public and private history," Fay calls for a more flexible, interpretive, and micro-focused understanding of the relationship between individuals and their contexts. She also champions auto/biography as both a means of entry into private lives and a lens through which to view those lives as part of a broader sociohistorical milieu.

The various authors assert that such a use of biography is consistent with traditional Arab and Islamic forms of representation - a claim that recenters the Middle East within the social sciences as a key site of knowl- 
edge-building and cultural negotiation. The authors anchor the present work by citing the prevalence of biography in premodern Middle Eastern writing and its functions as a barometer of community values and a record of sociopolitical change as important contributions to the social sciences. Framing Arabo-Islamic biography in this manner, and then validating that tradition's contribution to the modern and postmodern social sciences, is an important challenge to the idea that the autonomous individual, as an agent of history, is a construction of the Enlightenment.

The book is organized thematically - an arrangement that can be somewhat awkward, as the shifts in historical period and location are dramatic within each section and because the distinction between anthropological and historical pieces (grouped by discipline) is not always clear. Some authors are located firmly in one discipline; others seem less certain of their positions or view the merging of disciplinary traditions as an appropriate trend in postmodern research. However, Fay's dual goals of using biography to illuminate history and culture and understanding how biography constructs personal and communal identity are probably better served by such an arrangement than by a chronological or a locational grouping of texts.

The first section, "Critical Studies of Biography and Autobiography," outlines the arguments that the Arab-Muslim biographical tradition has much to contribute to contemporary social science and that it is the most effective mechanism for understanding the links between the public and the private in the Middle East. Judith Tucker's "Biography as History: The Exemplary Life of Khayr al-Din al Ramli" examines the construction of traditional biographies and their use of an individual life to "illuminat[e] the age" through the case of a seventeenth-century Palestinian jurist. Her engaging and well-supported analysis of how individual lives relate to and reflect history provides an interesting methodological contrast to Osama AbiMershed's "The Transmission of Knowledge and the Education of the "Ulama in Late $16^{\text {th }}$ Century Maghrib." Abi-Mershed also uses a single text (Muhammad ibn Maryam's biographical dictionary), but for a statistical study of how the "ulama were educated and how that education was related to their local context. This supports a thesis of increasing localization and variation in Islamic culture of the period. This is an interesting approach and a rich data source. However, many of his important arguments about what influences localization are relegated to lengthy endnotes, which weakens the text.

Steve Tamari's "Biography, Autobiography, and Identity in Early Modern Damascus" examines the representation of national and/or ethnic 
consciousness in works by Ismail al-Ajluni, Muhammad Khalil al-Muradi, and Muhammad ibn Kannan. His clearly argued piece presents three "circles of identity" for Damascenes of that time: international Islamic scholarship, Ottoman citizenship, and the Damascene quotidian. Marilyn Booth's "Infamous Women and Famous Wombs: Biography, Gender, and Islamist Concepts of Community in Contemporary Egypt" examines similar issues for modern women by analyzing their presentation in Egyptian biographical collections and the changing ideal identities constructed from their stories. Booth focuses explicitly on gender politics. She notes the dramatic shifts in what is considered "exemplary" about early Muslim women' lives and in the "ideal" roles for women based on those exemplars, and links those shifts to sociopolitical transformations within Egyptian society. Didier Monciaud's "Ideology, Identity, and Commitment in the Autobiography of Khalid Mohieddin" also examines personal engagement with the political in Egypt. However, his piece is plagued with typographical and editing errors and fails to explain what new light he sheds on either the man or the period under consideration.

Sections two and three, "Biography-History-Culture" and "Biography and the Anthropological Encounter," seem unnecessarily separated, as the borders between history and anthropology, and appear quite fluid. Both sections challenge the traditional categories of Middle Eastern historymakers by including women and cultural border-crossers, and explore the tensions within individuals and in cultures during transitional historical periods.

"Biography-History-Culture" uses the experiences of four individuals in the late seventeenth-through early twentieth-centuries to call for more nuanced understandings of Middle Eastern cultural and political history during those times. Mary Ann Fay's "Shawikar Qadin: Woman of Power and Influence in Ottoman Cairo" explores the roles of elite women during the neo-Mamluk period, using Qadin's biographical materials as clues to women's contributions to the Mamluk system's stability and continuance, and argued that women's power within this framework needs to be reexamined. Dina Rizk Khoury's engaging "Looking for the Modern: A Biography of an Iraqi Modernist" uses Jamal Sidqi al-Zahawi's biography to trace the emergence of a "sensibility of Arab modernity" at the end of the Ottoman period.

William Cleveland explores insider-outsider dynamics and the costs of colonialism in "The Worlds of George Antonius: Identity, Culture, and the Making of an Anglo-Arab in the pre-World War II Middle East," and links 
British exclusion of the Arab elite in the interwar period to the present crisis in Palestine. Garay Menicucci's "Kulthum Auda: The Forgotten Palestinian Ethnographer" examines a different kind of Palestinian bordercrosser (Auda married a Russian in 1914 and spent most of her life in the Soviet Union). He writes that women's memories as components of national discourse and the contribution of Palestinians outside the Arab world and Euro-America to the collective memory's formation are important elements of a richer understanding of Palestinian identity. While engaging, Menicucci's piece is more critical than any other of his focal culture. His comments about the continued oppression of Palestinian women are somewhat out of place in a text that is generally more even-handed.

"Biography and the Anthropological Encounter" explores previously muted experiences of cultural change by considering two Egyptian communities in flux. Nadje S. Al-Ali's "Between Political Epochs and Personal Lives: Formative Experiences of Egyptian Women Activists" is cogent and compelling, grounded in a strong theoretical framework, and attentive to the diversity of her population even as she addresses the typicality of her three focal cases. Anita H. Fabos' "Ambiguous Borders, Ambivalent Subjects: Being Sudanese in 20th Century Egypt," however, fails to provide the same kind of warrants for her claims as are present in Al-Ali's piece. Moreover, the validity of her assertions is undermined by her lack of representative data.

The final section, "Reflections on Writing Auto/Biographically," represents a dramatic shift in tone, focusing far more on text presentation than on elements of particular lives. Virginia Aksan and Cynthia Nelson offer contrasting perspectives on the importance of factual verifiability and the role of imagination in their respective chapters: "The Question of Writing Premodern Biographies of the Middle East" and "Writing Culture, Writing Lives: Fictional Boundaries." The final piece, Samar Attar's "Reflections on a Mixing of Fiction and Memoir in Lina: A Portrait of a Damascene Girl and The House on Arnus Square," makes the question of truth in biography even messier, as she claims that while her books are not autobiographies, they have "transformed a small portion of [her] life ... into a literary text." Closing with this selection is an interesting editorial choice, as in some ways it undermines the book's arguments for biography as a socio-scientific tool. However, it leaves the door open to more flexible, postmodern understandings of representational verity than are standard in socio-scientific writing.

This important collection of writings challenges many of the assumptions held by scholars of the modern and premodern Middle East. The indi- 
vidual pieces are diverse yet grounded in a solid theoretical framework that makes the overall argument for the inclusion of greater biographical study in works on the region compelling. When taken together, they should provoke social scientists to "listen" more carefully "to [the] silence" that is often held to characterize the Middle East historically and culturally during these periods.

Rachel Christina, Visiting Assistant Professor Institute for International Studies in Education University of Pittsburgh, Pittsburgh, Pennsylvania 